\title{
Temporal trends of essential omega-3 fatty acids in Atlantic and Pacific food webs as measured in eggs of Leach's storm-petrel Oceanodroma leucorhoa
}

\author{
Craig E. Hebert ${ }^{1, *}$, Neil M. Burgess ${ }^{2}$, John E. Elliott ${ }^{3}$ \\ ${ }^{1}$ Environment and Climate Change Canada, Science and Technology Branch, Ecotoxicology and Wildlife Health Division, \\ National Wildlife Research Centre, Ottawa, ON K1S 5B6, Canada \\ ${ }^{2}$ Environment and Climate Change Canada, Science and Technology Branch, Ecotoxicology and Wildlife Health Division, \\ Mount Pearl, NL A1N 4T3, Canada \\ ${ }^{3}$ Environment and Climate Change Canada, Science and Technology Branch, Ecotoxicology and Wildlife Health Division, \\ Pacific Wildlife Research Centre, Delta, BC V4K 3Y3, Canada
}

\begin{abstract}
Leach's storm-petrel Oceanodroma leucorhoa populations in the North Atlantic have declined in recent decades. The cause of those declines is not clear but one potential contributing factor could be reductions in the availability of essential nutrients due to changing marine ecology resulting from global warming. One group of particular concern is the omega-3 highly unsaturated fatty acids (n-3 HUFAs), in particular, eicosapentaenoic (EPA) and docosahexaenoic (DHA) acids. Dietary sources of EPA and DHA are required for normal growth and development in higher consumers, including birds. However, previous work has predicted increases in sea surface temperatures may cause declines in their availability. Here, we investigate this possibility by examining temporal trends (1992-2015) in EPA and DHA concentrations in Leach's storm-petrel eggs from 5 Canadian colonies: 2 on the Atlantic coast (Gull, Kent Islands) and 3 on the Pacific coast (Hippa, Storm, Cleland Islands). Neither EPA nor DHA concentrations in eggs decreased with time on either coast; rather, on the Atlantic coast, both EPA and DHA increased over the period of study. Carbon stable isotopes in the same eggs indicated that storm-petrels foraging in offshore, pelagic waters may have had increased access to n-3 HUFA. The data generated here provide a baseline for future comparisons. Ongoing regular monitoring of fatty acids in seabird eggs would be prudent given the likelihood of further increases in ocean temperatures.
\end{abstract}

KEY WORDS: Leach's storm-petrel - Oceanodroma leucorhoa - Essential fatty acids · Eicosapentaenoic acid · Docosahexaenoic acid · Stable isotopes · Global warming $\cdot$ Climate change

\section{INTRODUCTION}

Leach's storm-petrel Oceanodroma leucorhoa, hereafter storm-petrel, is the most widely distributed procellariiform breeding in the Northern Hemisphere (Pollet et al. 2021). In recent decades, however, populations in the Atlantic Ocean, including at the world's largest nesting colony at Baccalieu Island, Newfoundland (Sklepkovych \& Montevecchi 1989, Wilhelm et al. 2020), have shown significant declines (Robertson et al. 2006, Wilhelm et al. 2015, 2020, Pollet \& Shutler

\footnotetext{
${ }^{*}$ Corresponding author: craig.hebert@canada.ca
}

2018, but also see Duda et al. 2020). Most research on Canadian storm-petrel populations has occurred on colonies in Atlantic Canada. Much less has been done on the Pacific coast where population trends are unknown; however, Rennie et al. (2020) found that apparent survival of adult storm-petrels was much higher in the Pacific than on the Atlantic coast. Declines in storm-petrel populations in Atlantic Canada may be due, in part, to low survival of adults and young caused by a variety of factors including loss of habitat (D'Entremont et al. 2020), predation at nesting

(C) The Crown in the Right of Canada 2022. Open Access under Creative Commons by Attribution Licence. Use, distribution and reproduction are unrestricted. Authors and original publication must be credited. 
colonies (Stenhouse \& Montevecchi 1999, Robertson et al. 2006), offshore oil and gas development (Ellis et al. 2013, Hedd et al. 2018), strandings as a result of light attraction (Gjerdrum et al. 2021, Wilhelm et al. 2021), environmental contaminants such as mercury (Elliott \& Elliott 2016a, Burgess et al. 2018) and plastics (Bond \& Lavers 2013, Frith et al. 2020, Krug et al. 2021), and alterations to food availability caused by commercial fishing, ocean acidification and climate change (Hedd et al. 2009). Here, we focus on aspects of the last issue.

Sea surface temperatures (SST) in the North Pacific and North Atlantic oceans have increased through time, with changes in the latter region being more pronounced (Hansen et al. 2010, Belkin 2016). One of the ways in which SST affects seabird populations is through changes in food availability and quality, i.e. prey energy density (Diamond \& Devlin 2003). For storm-petrels, annual global mean surface (land and sea) temperature has been associated with hatching success at Kent Island in Atlantic Canada (Mauck et al. 2018). Hatching success exhibited a quadratic relationship with temperature, in that it increased to a critical threshold temperature, whereupon it declined. The initial positive effect of temperature may have been due to a lowering of thermoregulatory costs during incubation, while the negative effect of higher temperatures may have been caused by declines in food availability (Mauck et al. 2018).

Diamond \& Devlin (2003) found changes in prey energy density were important in regulating reproductive success in some species of Atlantic seabirds. In addition to this aspect of food quality, changes in nutrient content in the form of the availability of essential fatty acids is an issue that deserves consideration. Fatty acids are the main constituents of lipids, and when metabolized, they provide animals with energy. In addition to this vital role, some fatty acids are essential for normal growth and development (Brett \& Müller-Navarra 1997, Arts \& Kohler 2009). The long carbon-chain highly unsaturated omega-3 fatty acids (n-3 HUFAs) eicosapentaenoic acid (20:5n-3, EPA) and docosahexaenoic acid (22:6n-3, DHA) are of particular importance in this regard (Twining et al. 2016a). EPA and DHA are important regulators of growth and development in young birds (Twining et al. 2016b, 2018, Price et al. 2018) and of flight performance in birds travelling long distances (Guglielmo 2018). Storm-petrels can travel over $2000 \mathrm{~km}$ in a single foraging trip (Hedd et al. 2018) so adequate EPA and DHA availability may be important in enabling successful foraging and migration. However, higher consumers, such as sea- birds, cannot synthesize them. They must satisfy their EPA and DHA requirements from dietary sources that originate primarily from phytoplanktonbased food webs in marine and freshwater ecosystems (Hixson et al. 2015). Cold-water organisms generally have higher levels of EPA and DHA than organisms inhabiting warmer waters (McMeans et al. 2015) because they help to ensure proper function of cellular membranes in low temperature environments, including maintaining membrane fluidity (Arts \& Kohler 2009). There is growing concern, however, that climate change induced increases in water temperature may reduce the production of EPA and DHA at the base of the food web (Jónasdóttir 2019), resulting in reduced availability for higher trophic level consumers (Hixson \& Arts 2016, Colombo et al. 2017, 2020). This could be manifested either through alterations in the fatty acid composition of prey (Hixson \& Arts 2016, Jónasdóttir 2019, Colombo et al. 2020) or in overall declines in primary production in ecosystems such as the North Atlantic (Behrenfeld et al. 2013, Jónasdóttir 2019).

Declines in n-3 HUFA availability to higher trophic level organisms could result from changes in the fatty acid composition of organisms at the base of the food web, i.e. phytoplankton (Hixson \& Arts 2016), which constitute the main source of these essential compounds to higher consumers such as seabirds (Hixson \& Arts 2016). In Canadian marine environments, production of HUFAs such as EPA largely derives from spring diatom blooms (Hixson \& Arts 2016). Warming of coastal waters may result in changes in the structure of phytoplankton communities, with a transition from species rich in EPA and DHA, e.g. diatoms, to others (Behrenfeld et al. 2013, Jónasdóttir 2019). Ocean warming may also lead to increased stratification of water masses, limiting the transfer of nutrients from deep to surface waters (Jónasdóttir 2019). This could limit nutrient availability at the base of the food web, detrimentally affecting plankton growth, plankton lipid quality, and ultimately HUFA availability for higher trophic level organisms (Jónasdóttir 2019).

Here, we investigate possible declines in the food web availability of EPA and DHA by examining temporal trends in their concentrations in storm-petrel eggs over the past 3 decades at colonies in Atlantic and Pacific Canada. We hypothesize that temporal changes in egg fatty acid composition may be more apparent in Atlantic Canada because of greater historical increases in SST (Hansen et al. 2010, Belkin 2016).

Storm-petrels feed on zooplankton and small fish (Pollet et al. 2021), and investigating the fatty acid 
composition of storm-petrel tissues may provide insights into alterations in fatty acid availability at these lower trophic levels. Eggs are a useful matrix to evaluate changes in the fatty acid composition of bird diets (see Hebert et al. 2008 for an example) because the diet of breeding females is evident in the fatty acid composition of their eggs (Farrell 1998, Surai et al. 2001, Surai \& Speake 2008). Storm-petrels use both exogenous, i.e. locally-obtained, and endogenous resources for egg formation, but the former predominate (Bond \& Diamond 2010). Obtaining resources within a foraging range relatively close to the breeding colony is thought to be critical for successful breeding (Bond \& Diamond 2010), so changes in diet composition at the breeding colony should be evident in egg fatty acid composition.

Alterations in the resources used for egg formation may also be reflected in other dietary markers. Stable carbon isotopes $\left({ }^{13} \mathrm{C}:{ }^{12} \mathrm{C}\right.$, expressed as $\left.\delta^{13} \mathrm{C}\right)$ are useful in identifying the origins of food utilized by consumers, because they change very little (approximately $+0.4 \%$ per trophic level) as they pass through food webs (Post 2002). $\delta^{13} \mathrm{C}$ values can differentiate between sources of primary production in marine habitats (Miller et al. 2008), with pelagic primary producers being depleted in ${ }^{13} \mathrm{C}$. By measuring $\delta^{13} \mathrm{C}$ values in the tissues of consumers, such as stormpetrels, insights into their food sources can be gained.

Like carbon isotopes, stable sulfur isotopes $\left({ }^{34} \mathrm{~S}:{ }^{32} \mathrm{~S}\right.$, expressed as $\delta^{34} \mathrm{~S}$ ) may also be useful in indicating the origin of food resources. In open ocean waters, marine sulfate has a $\delta^{34} \mathrm{~S}$ value of $21 \%$ (Tostevin et al. 2014) while organic matter from terrestrial and freshwater environments has lower $\delta^{34} \mathrm{~S}$ values (Alling et al. 2008, Croisetière et al. 2009). Hence, tissues of consumers foraging in offshore habitats would be expected to have higher $\delta^{34} \mathrm{~S}$ values than those foraging in shallower, nearer shore waters (Fry \& Chumchal 2011, Willacker et al. 2017).

Stable nitrogen isotopes $\left({ }^{15} \mathrm{~N}:{ }^{14} \mathrm{~N}\right.$, expressed as $\delta^{15} \mathrm{~N}$ ) reflect organism trophic position because $\delta^{15} \mathrm{~N}$ values in tissues increase by $3-4 \%$ from one trophic level to the next (Minagawa \& Wada 1984). However, interpretation of $\delta^{15} \mathrm{~N}$ values in higher trophic level organisms must consider the possible effect of differences in $\delta^{15} \mathrm{~N}$ values of sources of inorganic nitrogen entering the base of the food web. Without adjusting for baselines, spatial comparisons are likely not appropriate (Post 2002, Dolgova et al. 2018).

By examining stable isotopes of carbon, sulfur, and nitrogen in eggs we investigate whether factors related to habitat use and diet may be influencing egg fatty acid concentrations.

\section{MATERIALS AND METHODS}

Storm-petrel eggs were collected at regular intervals as part of contaminant monitoring research in Atlantic and Pacific Canada (Elliott et al. 1989, 1992, Pearce et al. 1989, Burgess et al. 2013). Eggs collected from 5 Canadian colonies from 1992 to 2015 were examined in this study. Freshly-laid eggs were the focus of egg collections but stage of development at the time of egg processing was inconsistently assessed through time. Two colonies were located in marine waters of Atlantic Canada: Gull Island, Newfoundland and Labrador, and Kent Island, New Brunswick. Three colonies were located off the Pacific coast of British Columbia: Hippa Island, Storm Islands, and Cleland Island (Fig. 1). Storm-petrels begin to visit nesting colonies approximately 2 mo before egg laying (Pollet et al. 2021). Both members of a breeding pair occasionally occupy burrows during daylight 3 to 4 wk before laying, with copulation occurring during this time (Pollet et al. 2021). Bond \& Hobson (2015) estimated that yolk formation required 15 to $16 \mathrm{~d}$, with an additional approximately $6 \mathrm{~d}$ until the egg was laid. At colonies in the northeastern Atlantic Ocean, egg laying usually occurs during mid-June, with most clutches consisting of one egg (Pollet et al. 2021). For each annual colony collection, one freshly-laid egg was collected from 9 to 15 different nests. Calipers were used to measure maximum length and width $( \pm 1 \mathrm{~mm})$ of each egg and, identical to Gilmour et al. (2015), egg volume $\left(\mathrm{cm}^{3}\right)$ was calculated using Hoyt's (1979) formula:

$$
\text { Egg volume }=\left(0.51 \times\left(\text { length } \times \text { width }^{2}\right)\right) / 1000
$$

Annual mean egg volume was calculated for each site.

After collection, egg contents (yolk and albumen) were homogenized together, aliquoted and combined on an equal weight basis to form 3 pooled samples (see below for exceptions) from each colony for each time point. Each of the Atlantic Canada pools was comprised of 5 eggs; each Pacific Canada pool was comprised of 3 eggs (except for the single pool from Cleland Island in 1998, which was comprised of 13 eggs) (Gilbertson et al. 1987). These egg pools were stored frozen in the National Wildlife Specimen Bank (NWSB) at the National Wildlife Research Centre (NWRC) in Ottawa, ON, Canada. The NWSB is the largest repository of frozen wildlife tissues in Canada (Braune et al. 2010). To minimize the potential for temporal degradation of fatty acids in frozen material, samples were kept at $-40^{\circ} \mathrm{C}$ in large walk-in freezers and freeze-thaw events were avoided. Rudy et al. 


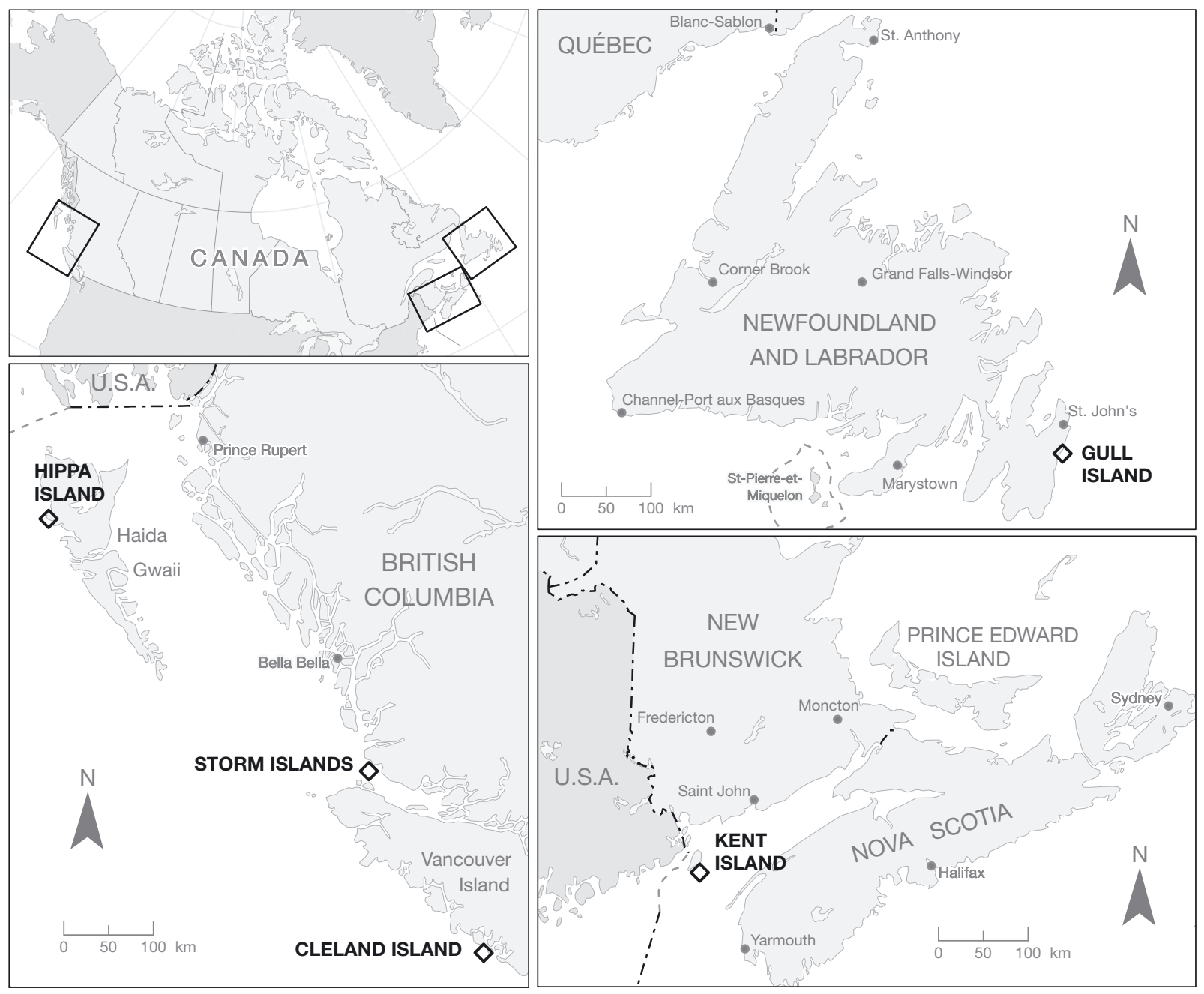

Fig. 1. Leach's storm-petrel eggs were collected from 5 locations: 2 in Atlantic Canada (Gull and Kent islands) and 3 in Pacific Canada (Hippa, Storm, and Cleland islands). Dashed line around St-Pierre-et-Miquelon: territorial waters of France

(2016) noted that for fish, n-3 HUFA degradation occurred primarily in species with high lipid content, i.e. charr ( 20\% lipid). Petrel eggs contain lower levels of lipid (Miller et al. 2014) so may not be as prone to fatty acid degradation. Furthermore, previous long-term ( 40 yr) longitudinal research on egg samples (herring gull Larus argentatus) stored in a similar manner showed no evidence of fatty acid degradation through time; in fact, older samples contained higher levels of $n-3$ fatty acids due to dietary change (see Hebert et al. 2008, 2020). We are not aware of studies that have evaluated fatty acid stability in frozen samples stored for many decades; therefore, we cannot rule out the possibility of oxidative degradation of fatty acids in these egg samples.

Fatty acid concentrations were determined in 3 egg pools per colony per yr (except where noted) from the following sites and years: Gull Island (1996, 2000,
2004, 2008, 2012), Kent Island (1992, 1996, 2000, 2004, 2012), Hippa Island (1995, 2003, 2007, 2011, 2015), Storm Islands (1994 (n=1), 2003, 2007, 2011, 2015), Cleland Island (1994, 1998 ( $\mathrm{n}=1), 2002,2006,2011$, 2015). All samples were analysed in 2019 using the same methods. We are not aware of other fatty acid data generated using storm-petrel eggs; however, information on fatty acids in other storm-petrel tissues is available for Atlantic Canada (Logan 2007). Fatty acid analysis comprised 3 steps: extraction of lipids, derivatization of their acyl chains to fatty acid methyl esters (FAMEs), and gas chromatography of the FAMEs. Thirty to $40 \mathrm{mg}$ of freeze dried (done at the time of fatty analysis analysis) egg contents were extracted 3 times in chloroform:methanol (2:1, v/v) (modified from Folch et al. 1957) and centrifuged at $4000 \mathrm{rpm}$ to remove non-lipid material. From a final volume of $2 \mathrm{ml}$, duplicate $200 \mu \mathrm{l}$ aliquots were placed 
into pre-weighed vessels, which were dried and reweighed on a Sartorius M5 electronic balance with $0.001 \mathrm{mg}$ precision to provide a quantitative measure of total lipid content. The remaining extract $(1.6 \mathrm{ml})$ was transferred to a $5 \mathrm{ml}$ Shimadzu vial (Sigma, no. $27319 \mathrm{U}$ ), evaporated to dryness using $\mathrm{N}_{2}$, and stored at $-80^{\circ} \mathrm{C}$ until derivatization. The lipids were re-suspended in $1.5 \mathrm{ml}$ toluene and $2 \mathrm{ml}$ of $\mathrm{H}_{2} \mathrm{SO}_{4} /$ methanol $(1 \%)$ were added before overnight methylation (16 h) in a water bath at $50^{\circ} \mathrm{C}$. FAMEs were extracted using hexane. The extract was evaporated to dryness under $\mathrm{N}_{2}$ and re-dissolved in $2 \mathrm{ml}$ hexane. A $250 \mu \mathrm{l}$ portion was used for fatty acid analysis. Fatty acid concentrations were quantified using a capillary gas chromatograph (Agilent 6890N) coupled with a flame ionization detector. Instrument configuration was splitless injection; Supelco SP-2560 column; $100 \mathrm{~m} \times 0.25 \mathrm{~mm}$ internal diameter; $0.20 \mathrm{~mm}$ thick film; oven temperature $140^{\circ} \mathrm{C}$ (hold $5 \mathrm{~min}$ ) to $240^{\circ} \mathrm{C}$ at $4^{\circ} \mathrm{C} \mathrm{min}^{-1}$, hold for $12 \mathrm{~min}$; He carrier gas, $1.2 \mathrm{ml} \mathrm{min}^{-1}$; flame ionization detector at $260^{\circ} \mathrm{C}_{i}$ injector at $260^{\circ} \mathrm{C}_{i}$ total run time of 42 min sample ${ }^{-1}$. A 37 component FAME standard (Supelco, no. 47885-U) was used to identify and quantify (4 point calibration curves) FAMEs in the samples by comparing their retention times to those of the FAME standard. Quality control was maintained through analysis of in-house reference materials, method blanks, and sample duplicates (mean relative percent difference $<5 \%$ ). Results were reported as milligrams of fatty acids per gram of tissue (dry weight).

Carbon, nitrogen, and sulfur stable isotopes were also measured in each egg pool. For carbon and nitrogen isotope analysis, analytical details are identical to those reported in Hebert \& Popp (2018). Briefly, $1.0 \pm 0.2 \mathrm{mg}$ (dry wt) of homogenized egg contents was encapsulated in tin. Stable nitrogen and carbon isotope analyses were conducted simultaneously using an Elementar IsotopeCube elemental analyzer (EA), followed by trap-and-purge separation and online analysis by continuous flow with a DeltaPlus Advantage isotope ratio mass spectrometer (Thermo Scientific) coupled with a ConFlo III. $\delta^{15} \mathrm{~N}$ is reported as \%o relative to AIR and normalized to internal standards $\left(\mathrm{C}-51\right.$ : nicotinamide $\left[\delta^{15} \mathrm{~N}=\right.$ 0.07, $\left.\delta^{13} \mathrm{C}=-22.95\right], \mathrm{C}-52$ : mix of ammonium sulfate and sucrose $[16.58,-11.94], \mathrm{C}-54$ : caffeine [-16.61, -34.46], C-55: glutamic acid [-3.98, -28.53]) calibrated to international $\delta^{15} \mathrm{~N}$ standards IAEA-N1 $(+0.4 \%)$, IAEA-N2 $(+20.3 \%)$, USGS-40 (-4.52\%) and USGS-41 $(47.57 \%)$. $\delta^{13} \mathrm{C}$ is reported as \%o relative to Vienna Pee Dee Belemnite normalized to the internal standards described above calibrated to international standards IAEA-CH-6 (-10.4\%), NBS-22 (-29.91\%), USGS-40 (-26.24\%) and USGS$41(37.76 \%)$. A mathematical correction, based on sample C:N content and derived specifically for avian eggs (Elliott \& Elliott 2016b), was used to adjust $\delta^{13} \mathrm{C}$ values for sample lipid content. For organic sulfur isotope analysis, samples were encapsulated in tin with at least twice the sample weight of tungsten oxide $\left(\mathrm{WO}_{3}\right)$. Samples were flash-combusted in an EA (Isotope Cube, Elementar) and released gases carried by helium through the EA to be cleaned, then separated. Pure $\mathrm{SO}_{2}$ gas was then carried into a Delta Plus XP isotope ratio mass spectrometer (Thermo Finnigan) via a Conflo IV interface for sulfur isotope determination. $\delta^{34} \mathrm{~S}$ is reported as \% relative to Vienna Cañon Diablo Troilite normalized to an internal standard (S-6).

Quality control of stable isotope measurements was maintained through analysis of in-house reference materials (control limits \pm 3 standard deviations) and sample duplicates (one duplicate for every 10 samples; relative percent difference $<5 \%$ ). Analytical precision $( \pm 0.2 \%)$ was based on internal standard C-55.

Linear regression analysis was used to examine temporal trends in egg EPA and DHA concentrations and egg volume at each colony. Correlation analysis was used to examine relationships between egg concentrations of EPA and DHA, stable isotope values, and volume. Stable isotope biplots $\left(\delta^{13} \mathrm{C}\right.$ versus $\left.\delta^{34} \mathrm{~S}\right)$ were used to visualize differences in the isotopic composition of eggs among colonies. Inter-site differences in mean egg $\delta^{13} \mathrm{C}, \delta^{34} \mathrm{~S}$, and $\delta^{15} \mathrm{~N}$ values were evaluated using ANOVA followed by Tukey's HSD test. $\delta^{15} \mathrm{~N}$ values associated with nitrogen entering the base of the food web can differ greatly across sites, thereby affecting $\delta^{15} \mathrm{~N}$ values in consumer tissues (Hebert \& Wassenaar 2001). Hence, when using $\delta^{15} \mathrm{~N}$ values to assess organism trophic position it may be inappropriate to compare raw $\delta^{15} \mathrm{~N}$ values without adjusting for baseline differences in $\delta^{15} \mathrm{~N}$ (Post 2002, Dolgova et al. 2018). In this study, it was not possible to conduct such an adjustment, so inter-site differences in egg $\delta^{15} \mathrm{~N}$ values likely reflect not only trophic position but also inter-site differences in baseline nitrogen isotope values. Hence, inter-site differences in egg $\delta^{15} \mathrm{~N}$ values are not emphasized here. Normality (P-P plots, Q-Q plots, Shapiro-Wilk tests) and homogeneity of variance (Levene tests) assumptions underlying the use of parametric statistics were tested using data residuals. All statistical analyses were conducted using Statistica Ver 12 (StatSoft Inc., Tulsa, Oklahoma, USA) with $\alpha=0.05$. 


\section{RESULTS}

All egg morphometric, stable isotope, and fatty acid data are available in Table S1 in the Supplement at www.int-res.com/articles/suppl/m684p199_ supp.xlsx.

\subsection{Atlantic Canada colonies}

\subsubsection{Temporal trends}

Concentrations of EPA and DHA in egg pools increased through time at both Gull Island (EPA R ${ }^{2}$ $=0.40, F(1,13)=8.8, \mathrm{p}=0.01 ; \mathrm{DHA} \mathrm{R}^{2}=0.64, F(1,13)$ $=23.5, \mathrm{p}<0.001)$ and Kent Island $(\mathrm{EPA}$ $\mathrm{R}^{2}=0.64, F(1,13)=23.2, \mathrm{p}<0.001$; DHA R $R^{2}=0.51, F(1,13)=13.5, \mathrm{p}=$ 0.003) (Fig. 2). Egg volume showed no temporal change at either Gull $\left(\mathrm{R}^{2}=\right.$ $0.01, F(1,13)=0.1, \mathrm{p}=0.77)$ or Kent Island $\left(\mathrm{R}^{2}=0.11, F(1,13)=1.6, \mathrm{p}=\right.$ 0.22).

\subsubsection{Stable isotope relationships}

At Gull Island, egg $\delta^{13} \mathrm{C}$ values were related to egg EPA and DHA concentrations (EPA Pearson $\mathrm{r}=-0.66$, $\mathrm{p}=0.007$; DHA $\mathrm{r}=-0.71, \mathrm{p}=0.003$ ) (Fig. 3A). No such relationships were observed at Kent Island (EPA $\mathrm{r}=-0.17$, $\mathrm{p}=0.54 ;$ DHA $\mathrm{r}=0.05, \mathrm{p}=0.86$ ).

Egg $\delta^{15} \mathrm{~N}$ values were not related to egg EPA or DHA concentrations at Gull Island (EPA $r=0.10, p=0.72$; DHA $r=0.21, p=0.46)$. At Kent Island, egg $\delta^{15} \mathrm{~N}$ values were negatively correlated with EPA concentrations $(\mathrm{r}=-0.57, \mathrm{p}=0.03)$ but not DHA $(\mathrm{r}=-0.43, \mathrm{p}=0.11)$.

Egg $\delta^{34} \mathrm{~S}$ values were not related to egg EPA or DHA concentrations at Gull Island (EPA $r=-0.11, p=0.69$; DHA $r=-0.04, p=0.88)$. At Kent Island, egg $\delta^{34} \mathrm{~S}$ values were negatively related to both egg EPA and DHA concentrations (EPA r $=-0.75, \mathrm{p}=0.001$; DHA $r=-0.65, \mathrm{p}=0.009$ ) (Fig. 4).

Egg volume was not correlated with any of the stable isotope measurements at Gull Island $\left(\delta^{13} \mathrm{C} \mathrm{r}=0.09, \mathrm{p}=0.74\right.$; $\left.\delta^{15} \mathrm{Nr}=0.18, \mathrm{p}=0.53 ; \delta^{34} \mathrm{~S} \mathrm{r}=-0.09, \mathrm{p}=0.76\right)$. At Kent Island, egg volume was correlated with egg $\delta^{15} \mathrm{~N}$ values ( $\mathrm{r}=0.57, \mathrm{p}=0.03$ ) (Fig. 5) but not related to egg $\delta^{13} \mathrm{C}$ or $\delta^{34} \mathrm{~S}$ values $\left(\delta^{13} \mathrm{C} \mathrm{r}=0.23, \mathrm{p}=0.41 ; \delta^{34} \mathrm{~S} \mathrm{r}=\right.$ $0.35, \mathrm{p}=0.20$ ).

\subsection{Pacific Canada colonies}

\subsubsection{Temporal trends}

Concentrations of EPA and DHA in egg pools showed no temporal trend at any of the 3 Pacific colonies (Hippa Island: EPA $\mathrm{R}^{2}=0.04, F(1,13)=0.5$, $\mathrm{p}=0.49 ;$ DHA R ${ }^{2}=0.03, F(1,13)=0.5, \mathrm{p}=0.52 ;$ Storm
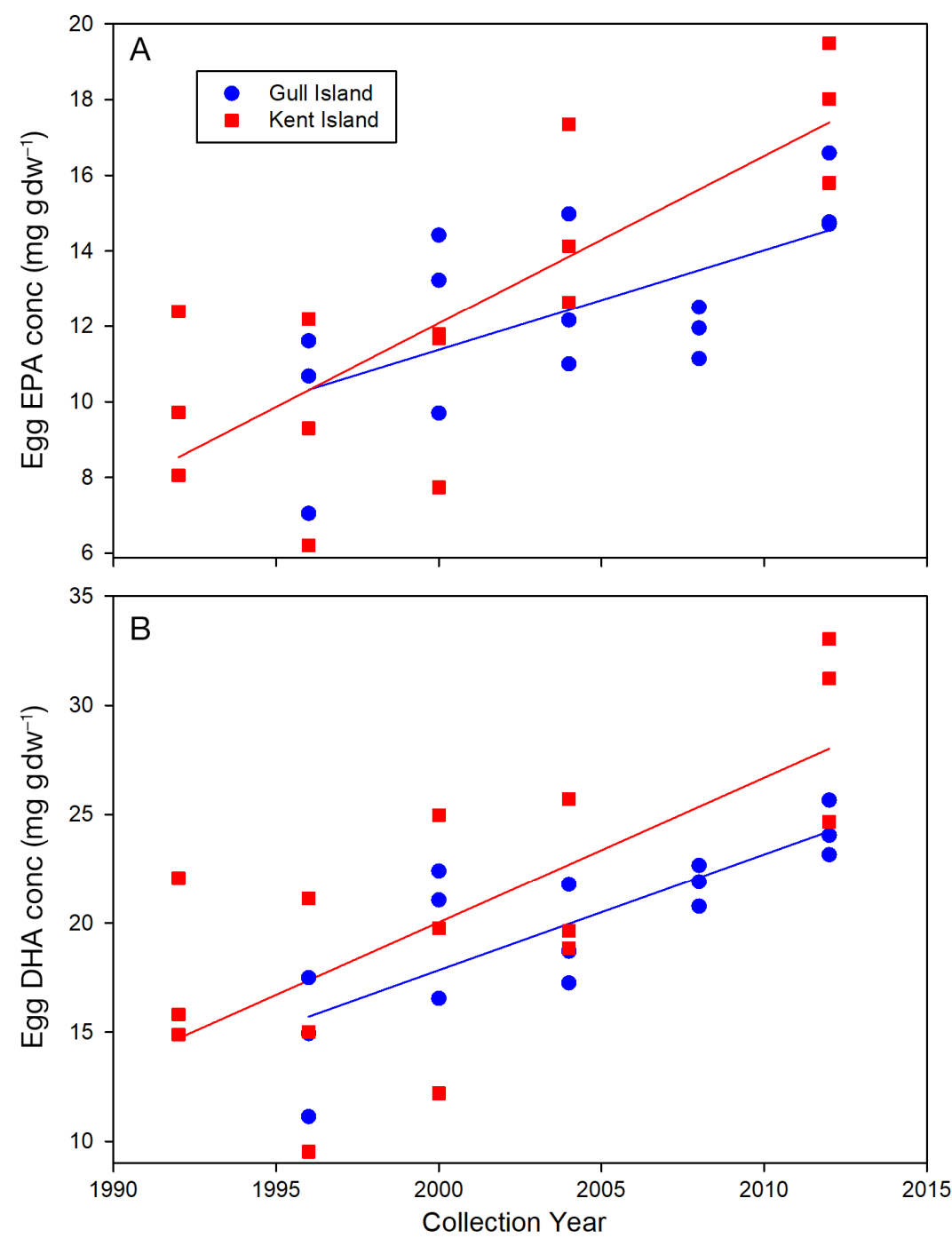

Fig. 2. Temporal trends in (A) EPA and (B) DHA concentrations in eggs from 2 Atlantic Ocean storm-petrel colonies (Gull Island EPA $R^{2}=0.40, p=0.01$, DHA $\mathrm{R}^{2}=0.64, \mathrm{p}<0.001$; Kent Island EPA $\mathrm{R}^{2}=0.64, \mathrm{p}<0.001, \mathrm{DHA} \mathrm{R}^{2}=0.51, \mathrm{p}=$ 0.003). The Pacific Ocean colonies showed no trends through time 

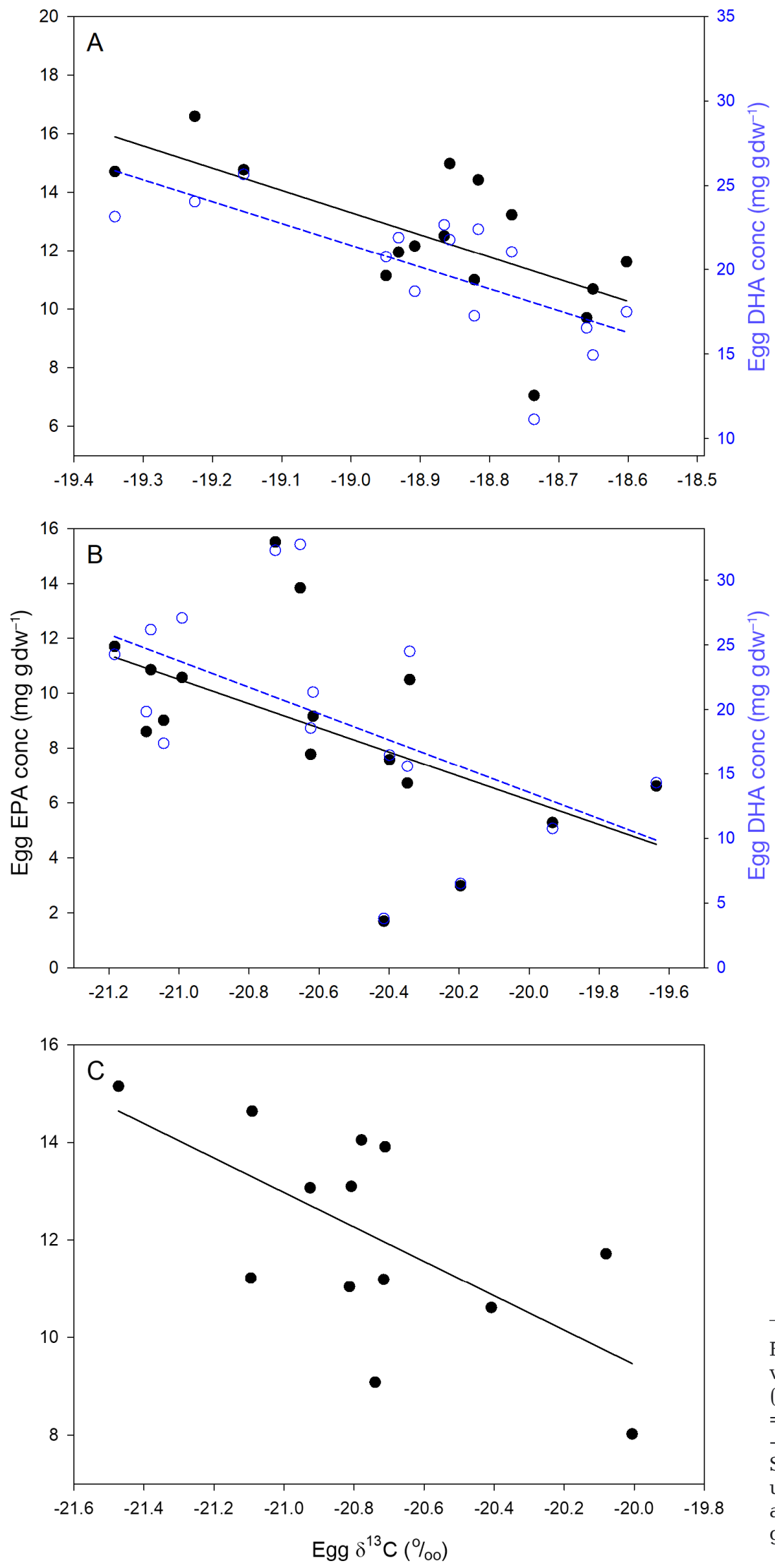

Islands: $\mathrm{EPA} \mathrm{R}^{2}=0.22, F(1,11)=3.2$, $\mathrm{p}=0.10 ;$ DHA R ${ }^{2}=0.12, F(1,11)=1.5$, $\mathrm{p}=0.25$; Cleland Island: $\mathrm{EPA} \mathrm{R}^{2}=0.09$, $F(1,14)=1.3, \mathrm{p}=0.27$; DHA R ${ }^{2}=0.09$ ， $F(1,14)=1.4, p=0.25)$. Egg volume decreased through time at Hippa Island $\left(\mathrm{R}^{2}=0.34, F(1,10)=5.1, \mathrm{p}=\right.$ 0.048) (Fig. 5) but not at Storm $\left(R^{2}=\right.$ $0.01, F(1,10)=0.1, \mathrm{p}=0.80$ ) or Cleland $\left(\mathrm{R}^{2}=0.03, F(1,11)=0.3, \mathrm{p}=0.57\right)$ islands.

\subsubsection{Stable isotope relationships}

Hippa Island egg $\delta^{13} \mathrm{C}$ values were not correlated with egg EPA $(\mathrm{r}=$ $-0.12, \mathrm{p}=0.67)$ or DHA $(\mathrm{r}=-0.25, \mathrm{p}=$ $0.93)$ concentrations. At Storm Islands, egg $\delta^{13} \mathrm{C}$ values were correlated with EPA $(r=-0.66, p=0.02$; Fig. $3 C)$ but not DHA $(\mathrm{r}=-0.43, \mathrm{p}=0.14)$. At Cleland Island, egg $\delta^{13} \mathrm{C}$ values were correlated with both egg EPA ( $\mathrm{r}=-0.54$, $\mathrm{p}=0.03)$ and DHA $(\mathrm{r}=-0.54, \mathrm{p}=0.03)$ concentrations.

Egg $\delta^{15} \mathrm{~N}$ values were correlated with egg EPA concentrations at Hippa Island only $(\mathrm{r}=-0.56, \mathrm{p}=0.03)$. No other significant relationships existed between egg $\delta^{15} \mathrm{~N}$ values and egg $\mathrm{n}-3$ fatty acid concentrations at Hippa (DHA $\mathrm{r}=-0.49, \mathrm{p}=0.07$ ), Storm (EPA $\mathrm{r}=-0.37, \mathrm{p}=0.21$; DHA $\mathrm{r}=-0.22, \mathrm{p}=$ 0.47 ) or Cleland (EPA $\mathrm{r}=-0.28, \mathrm{p}=$ 0.30 ; DHA $\mathrm{r}=-0.26, \mathrm{p}=0.33$ ) islands.

Egg $\delta^{34} \mathrm{~S}$ values were not correlated with egg EPA or DHA concentrations at Hippa (EPA $\mathrm{r}=-0.21, \mathrm{p}=0.46$; DHA $\mathrm{r}=-0.15, \mathrm{p}=0.58)$, Storm (EPA $\mathrm{r}=$ $0.34, p=0.25 ;$ DHA $r=0.15, p=0.62$ ) or Cleland (EPA $\mathrm{r}=0.23, \mathrm{p}=0.40$; DHA $r=0.22, p=0.40$ ) islands.

Fig. 3. Negative relationship between egg $\delta^{13} \mathrm{C}$ values and egg EPA and DHA concentrations at (A) Gull Island (EPA $r=-0.66, p=0.007$; DHA $r$ $=-0.71, \mathrm{p}=0.003)$, (B) Cleland Island (EPA $\mathrm{r}=$ $-0.54, p=0.03$; DHA $r=-0.54, p=0.03)$, and $(C)$ Storm Island (EPA $\mathrm{r}=-0.66, \mathrm{p}=0.02 ; \delta^{13} \mathrm{C}$ values were not correlated with DHA). EPA data are represented by closed symbols and solid regression lines, DHA data by open symbols and dashed regression lines 


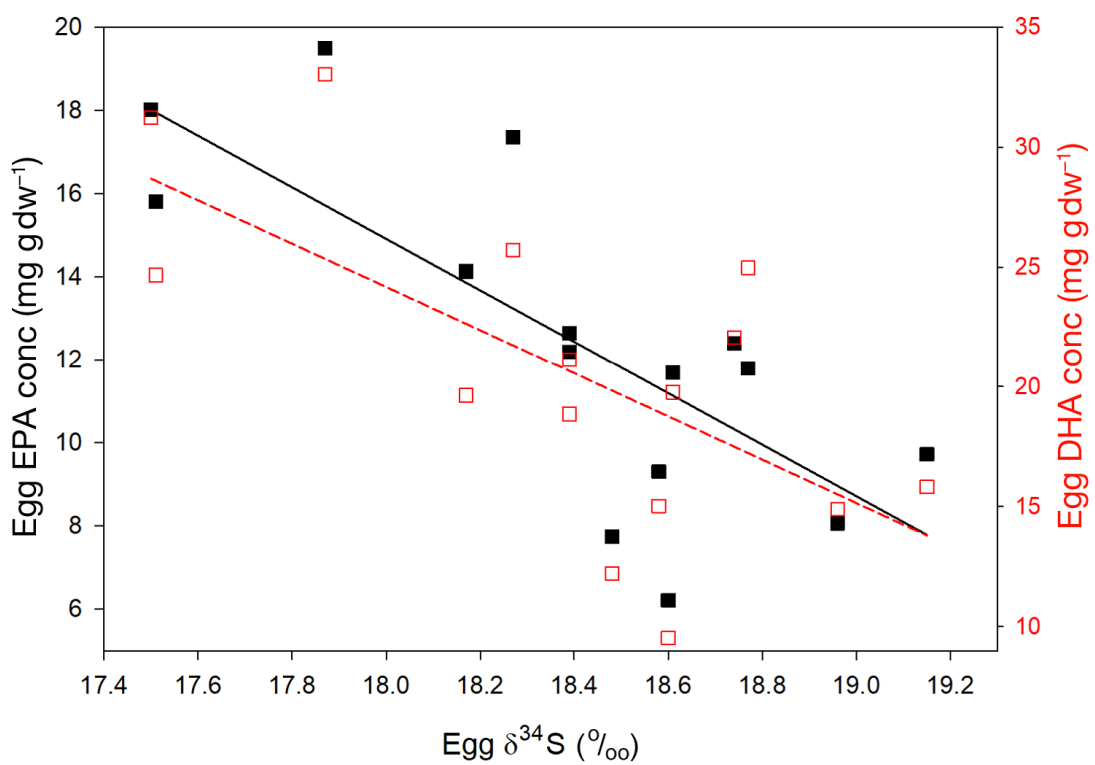

Fig. 4. Negative relationship between egg $\delta^{34} \mathrm{~S}$ values and egg EPA and DHA concentrations at Kent Island (EPA $r=-0.75, p=0.001$; DHA $r=-0.65, p=$ 0.009). EPA data are represented by closed symbols and solid regression lines, DHA data by open symbols and dashed regression lines

Egg volume was not correlated with any of the stable isotope measures at Hippa $\left(\delta^{13} \mathrm{C} \mathrm{r}=0.53, \mathrm{p}=0.08\right.$; $\left.\delta^{15} \mathrm{~N} \mathrm{r}=0.06, \mathrm{p}=0.86 ; \delta^{34} \mathrm{~S} \mathrm{r}=-0.42, \mathrm{p}=0.18\right)$, Storm Island $\left(\delta^{13} \mathrm{Cr}=0.07, \mathrm{p}=0.83 ; \delta^{15} \mathrm{Nr}=0.11, \mathrm{p}=0.74 ; \delta^{34} \mathrm{~S}\right.$ $\mathrm{r}=-0.17, \mathrm{p}=0.59)$ or Cleland Islands $\left(\delta^{13} \mathrm{C} \mathrm{r}=-0.24\right.$, $\mathrm{p}=0.42 ; \delta^{15} \mathrm{Nr}=-0.38, \mathrm{p}=0.20 ; \delta^{34} \mathrm{Sr}=-0.21, \mathrm{p}=0.49$ ).

\subsection{Inter-colony comparisons}

Mean egg $\delta^{13} \mathrm{C}, \delta^{34} \mathrm{~S}$, and $\delta^{15} \mathrm{~N}$ values differed among the 5 breeding locations $\left(\delta^{13} \mathrm{C}\right.$ Welch's $F_{4,33}=$ $154.9, \mathrm{p}<0.001 ; \delta^{34} \mathrm{~S}$ Welch's $F_{4,32}=47.4, \mathrm{p}<0.001$; $\delta^{15} \mathrm{~N}$ Welch's $\left.F_{4,32}=48.0, \mathrm{p}<0.001\right)$. Egg $\delta^{13} \mathrm{C}$ values were less negative at the Atlantic colonies (Fig. $6) . \delta^{34} \mathrm{~S}$ values in eggs differed among colonies, with the lowest values observed at Kent Island (Fig. 6). Egg $\delta^{15} \mathrm{~N}$ values were statistically different across all colonies, with the exception of Gull and Kent Islands which were not different from each other. Egg $\delta^{15} \mathrm{~N}$ values were greatest at Cleland Island $($ mean $=16.03 \%)$, followed by Storm $(14.80 \%)$, Hippa (13.72\%), Gull (12.50\%o), and Kent (12.38\%o). As mentioned in the Methods section, egg $\delta^{15} \mathrm{~N}$ values unadjusted for baseline $\delta^{15} \mathrm{~N}$ values are complicated to interpret in terms of organism trophic position. Baseline adjustment was not possible in this study so inter-site differences in egg $\delta^{15} \mathrm{~N}$ values are not discussed further.

\section{DISCUSSION}

Despite reported increases in SST, particularly in the North Atlantic (Hansen et al. 2010, Belkin 2016), we found no evidence of reductions in food web availability of EPA or DHA as indicated by their concentrations in storm-petrel eggs. On the contrary, eggs collected from the 2 North Atlantic colonies exhibited increases in EPA and DHA concentrations through time. It is possible that degradation of fatty acids during storage contributed to this result. However, relationships between egg EPA and DHA concentrations and stable carbon and sulfur isotopes suggested that the fatty acid data were providing insights into petrel diets similar to those inferred from stable isotopes, which are unaffected by frozen storage (Sweeting et al. 2004).

At the Atlantic breeding colonies there was no temporal change in egg volume. This finding was consistent with previous work at Gull and nearby Great islands (Pollet et al. 2021). Previous research indicated that resource availability was not a limiting factor affecting stormpetrel reproduction, with only very small declines in egg size between original and replacement clutches (Bond \& Hobson 2015). However, in this study, there was a relationship between egg volume and egg $\delta^{15} \mathrm{~N}$ values at Kent Island, suggesting that consumption of higher trophic level prey may have had a beneficial effect on resources available for egg formation. Fairhurst et al. (2015) reported a positive impact of higher trophic level feeding on reduced stress levels in storm-petrels.

Changes in planktonic physiology and planktonic community composition are likely occurring due to climate change (Barton et al. 2016). These alterations could decrease n-3 HUFA availability for stormpetrels if warmer water temperatures reduce the need for $\mathrm{n}-3$ fatty acids to maintain membrane fluidity in plankton (Arts \& Kohler 2009). It is also possible that changes in the species composition of marine food webs (resulting in corresponding changes in the fatty acid profile of prey) could have affected storm-petrel diets to the extent that they overshadowed any declines that may have occurred in n-3 HUFA availability at the base of the food web (Hedd et al. 2009). The diet of Pacific and Atlantic stormpetrels largely consists of zooplankton (Frith et al. 

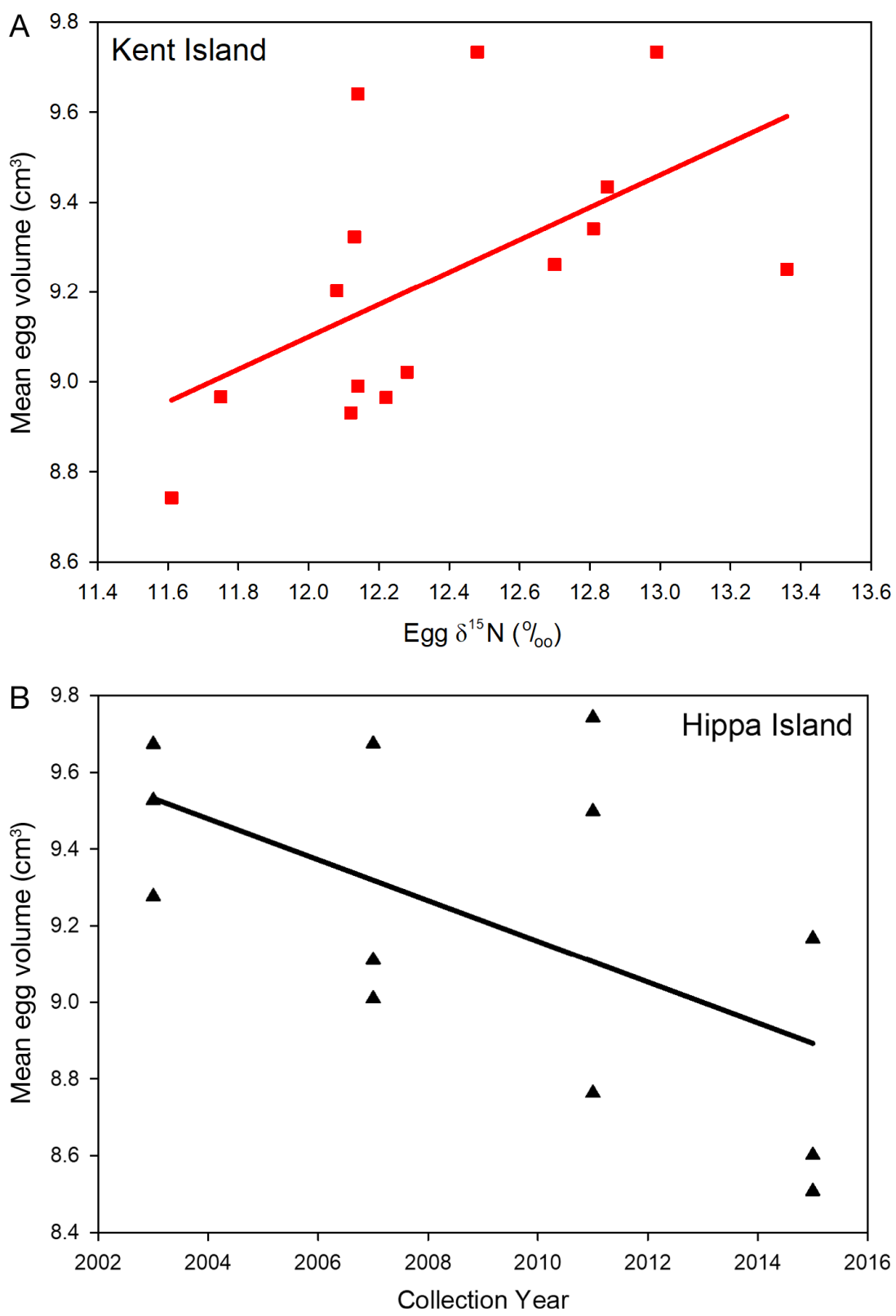

Fig. 5. Egg volume increased with egg $\delta^{15} \mathrm{~N}$ values at $(\mathrm{A}) \mathrm{Kent}$ Island $(\mathrm{r}=0.57$, $\mathrm{p}=0.03)$ and decreased through time at (B) Hippa Island $(\mathrm{r}=-0.58, \mathrm{p}=0.048)$

2020) and fish, with myctophids (lantern fishes) being particularly important (Vermeer \& Devito 1988, Vermeer et al. 1988, Hedd et al. 2009). Lantern fishes undergo a diel vertical migration from deep waters to the surface at night where they feed on plankton (Hudson et al. 2014). This makes them vulnerable to predation by storm-petrels, which are known to forage nocturnally (Vermeer \& Devito 1988, Hedd et al. 2009). However, alterations in the relative abundance and availability of different prey types would be expected to influence the fatty acid make-up of storm-petrel tissues, including eggs. Changes in the annual composition of storm-petrel diets have been documented (Hedd et al. 2009, Frith et al. 2020), and similar changes could have contributed to the egg fatty acid and stable isotope patterns observed here.

At 3 (Gull, Storm, Cleland) of the 5 colonies there were negative relationships between egg n-3 HUFA concentrations and $\delta^{13} \mathrm{C}$ values. One possible explanation for this result is that feeding on more pelagic food increased access to n-3 HUFAs. Consistent with this interpretation were the intercolony differences observed in egg $\delta^{13} \mathrm{C}$ values. Hedd et al. (2018) tracked the foraging movements of nesting storm-petrels at a number of colonies in Atlantic Canada. Birds from most colonies foraged well offshore in pelagic waters. However, storm-petrels from Kent Island were an exception; they foraged to a greater extent over shallower waters. The less negative $\delta^{13} \mathrm{C}$ values of Kent Island eggs were consistent with their different foraging habits, as were the lower $\delta^{34} \mathrm{~S}$ values compared to eggs from Gull Island. Biota using shallower areas may be influenced to a greater extent by riverine/terrestrial inputs of sulfur, which would be expected to have lower $\delta^{34} \mathrm{~S}$ than marine regions dominated by sulfate $\delta^{34}$ S values (Peterson \& Fry 1987).

Further investigation of the mechanisms responsible for the increased concentrations of EPA and DHA in Atlantic storm-petrel eggs is beyond the scope of this study. Our goal was to investigate possible temporal declines in n-3 HUFA availability to storm-petrels as a possible factor contributing to declines in their populations. Based upon the results presented here, there is no evidence to suggest that declines in n-3 HUFA availability during the period of egg formation has played such a role. Another aspect that needs to be considered, however, is n-3 HUFA availability during the chick growth and fledging periods, as adequate supplies of these essential nutrients are critical for development in birds (Twining et al. 2016b, Lamarre et al. 2021). 


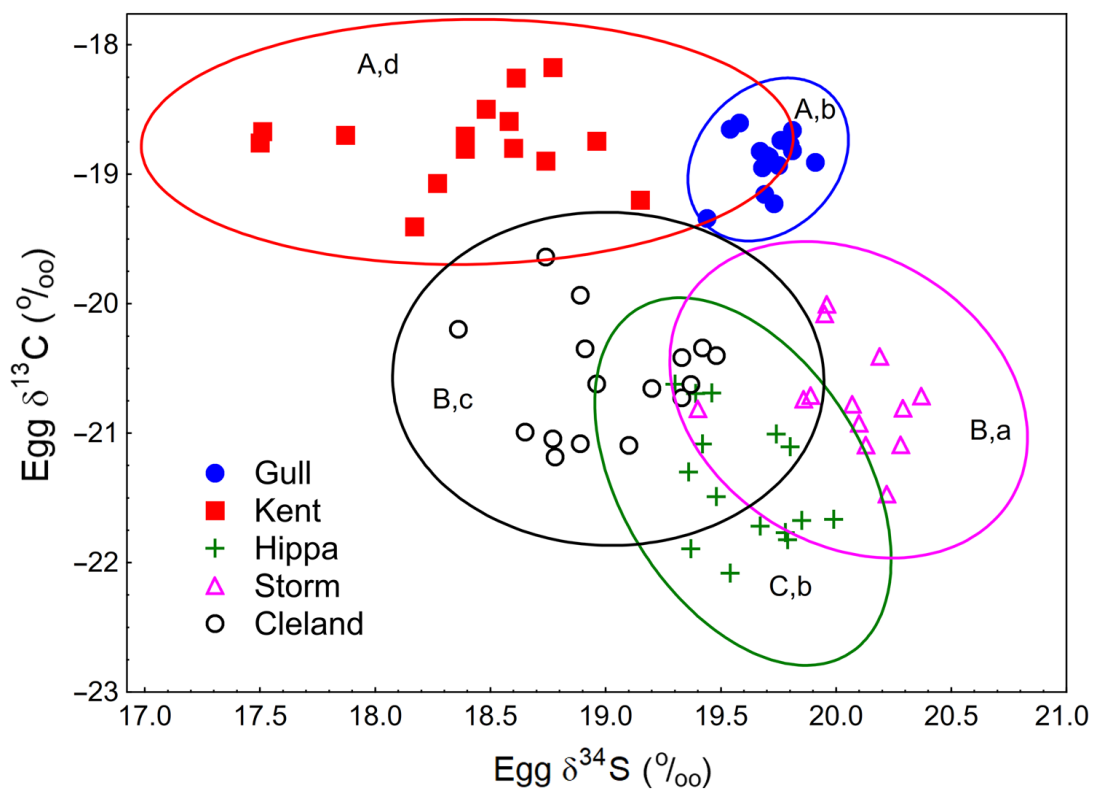

Fig. 6. Biplot of $\delta^{34} \mathrm{~S}$ versus $\delta^{13} \mathrm{C}$ values in Leach's storm-petrel eggs from 2 Atlantic colonies (Gull and Kent Islands) and 3 Pacific colonies (Hippa, Storm, and Cleland Islands). Data from all years are included and 95\% confidence ellipses are shown for each colony. Letters inside ellipses indicate statistically significant inter-colony differences in egg $\delta^{13} \mathrm{C}$ (uppercase letters) and $\delta^{34} \mathrm{~S}$ (lowercase letters) values. Colonies sharing the same letter are not different (ANOVA followed by Tukey's HSD test)

Worldwide, many factors are affecting petrel populations and diverse conservation actions are required (Rodríguez et al. 2019). However, future measurement of fatty acid concentrations in eggs of storm-petrels and other seabird species would be prudent. If efforts to curb global warming are not successful, increases in SST will likely continue. Recent SST increases in the North Pacific Ocean are concerning and may foreshadow future change with inordinate effects on other regions such as the Arctic (Praetorius et al. 2018). Ongoing, long-term contaminant monitoring programs involving Pacific, Arctic, and Atlantic Canada seabirds provide an opportunity to track changes in a variety of critical endpoints, e.g. n-3 HUFAs, that may be affected by ocean warming or other emerging stressors such as ocean acidification (Rossoll et al. 2012, Diaz-Gil et al. 2015, Dörner et al. 2020).

Acknowledgements. Numerous individuals assisted with egg collection over the years, including Ian Moul and Sandi Lee (PWRC). NWRC Laboratory Services staff are thanked for their expert handling and processing of samples. Lana Dolgova (NWRC) and Sandi Lee provided egg morphology data. Andy Murray (NWRC) created Fig. 1. François Cyr (NWRC) conducted the fatty acid analyses. The Jan Veizer Stable Isotope Laboratory at the University of Ottawa conducted the stable isotope analyses. The comments of 3 anonymous reviewers greatly improved the manuscript.

\section{LITERATURE CITED}

Alling V, Humborg C, Mörth CM, Rahm L, Pollehne F (2008) Tracing terrestrial organic matter by $\delta^{34} \mathrm{~S}$ and $\delta^{13} \mathrm{C}$ signatures in a subarctic estuary. Limnol Oceanogr 53:2594-2602

Arts MT, Kohler CC (2009) Health and condition in fish: the influence of lipids on membrane competency and immune response. In: Arts MT, Wainman BC (eds) Lipids in aquatic ecosystems. SpringerVerlag, New York, NY, p 237-255

Barton AD, Irwin AJ, Finkel ZV, Stock CA (2016) Anthropogenic climate change drives shift and shuffle in North Atlantic phytoplankton communities. Proc Natl Acad Sci USA 113:2964-2969

Behrenfeld MJ, Doney SC, Lima I, Boss ES, Siegel DA (2013) Annual cycles of ecological disturbance and recovery underlying the subarctic Atlantic spring plankton bloom. Global Biogeochem Cycles 27:526-540

Belkin I (2016) Chapter 5.2: Sea surface temperature trends in large marine ecosystems. In: IOC-UNESCO and UNEP Large marine ecosystems: status and trends. United Nations Environment Programme, Nairobi, p 101-109

Bond AL, Diamond AW (2010) Nutrient allocation for egg production in six Atlantic seabirds. Can J Zool 88:1095-1102

Bond AL, Hobson KA (2015) Relaying propensity and characteristics of replacement clutches of Leach's stormpetrels (Oceanodroma leucorhoa). Can J Zool 93: 181-185

Bond AL, Lavers JL (2013) Effectiveness of emetics to study plastic ingestion by Leach's Storm-Petrels (Oceanodroma leucorhoa). Mar Pollut Bull 70:171-175

Braune BM, Savard G, Wakeford BJ, McGoldrick DJ (2010) Environment Canada's national wildlife specimen bank: a valuable resource for monitoring and research. In: Isobe T, Nomiyama K, Subramanian A, Tanabe S (eds) Interdisciplinary Studies on Environmental Chemistry-Environmental Specimen Bank. TERRAPUB, Tokyo, p 25-32

Brett MT, Müller-Navarra DC (1997) The role of highly unsaturated fatty acids in aquatic foodweb processes. Freshw Biol 38:483-499

* Burgess NM, Bond AL, Hebert CE, Neugebauer WE, Champoux L (2013) Mercury trends in herring gull (Larus argentatus) eggs from Atlantic Canada, 1972-2008: temporal change or dietary shift? Environ Pollut 172:216-222

Burgess NM, Hedd A, Pollet IL, Mauck RA and others (2018) Spatial differences in mercury exposure in blood and eggs of a declining seabird in Atlantic Canada: Leach's stormpetrel. 39th Annu Meet Soc Enviro Chem Tox North America, Sacramento, CA, November 4-8, Society of Environmental Toxicology and Chemistry, Pensacola, FL

KColombo SM, Wacker A, Parrish CC, Kainz MJ, Arts MT (2017) A fundamental dichotomy in long-chain polyunsaturated fatty acid abundance between and within marine and terrestrial ecosystems. Environ Rev 25:163-174

Colombo SM, Rodgers TFM, Diamond ML, Bazinet RP, Arts MT (2020) Projected declines in global DHA availability 
for human consumption as a result of global warming. Ambio 49:865-880

Croisetière L, Hare L, Tessier A, Cabana G (2009) Sulphur stable isotopes can distinguish trophic dependence on sediments and plankton in boreal lakes. Freshw Biol 54: 1006-1015

'ㅡㄹ Mauck RA, Ronconi RA (2020) Breeding population decline and associations with nest site use of Leach's storm-petrels on Kent Island, New Brunswick from 2001 to 2018. Avian Conserv Ecol 15:11

Niamond AW, Devlin CM (2003) Seabirds as indicators of changes in marine ecosystems: ecological monitoring on Machias Seal Island. Environ Monit Assess 88:153-175

* Díaz-Gil C, Catalan IA, Palmer M, Faulk CK, Fuiman LA (2015) Ocean acidification increases fatty acids levels of larval fish. Biol Lett 11:20150331

Dolgova S, Popp BN, Courtoreille K, Espie RHM and others (2018) Spatial trends in a biomagnifying contaminant: application of amino acid compound specific stable nitrogen isotope analysis to the interpretation of bird mercury levels. Environ Toxicol Chem 37:1466-1475

* Dörner I, Hauss H, Aberle N, Lohbeck K, Spisla C, Riebesell U, Ismar-Rebitz SMH (2020) Ocean acidification impacts on biomass and fatty acid composition of a post-bloom marine plankton community. Mar Ecol Prog Ser 647:49-64

* Duda MP, Robertson GJ, Lim JE, Kissinger JA and others (2020) Striking centennial-scale changes in the population size of a threatened seabird. Proc R Soc B 287 : 20192234

Elliott KH, Elliott JE (2016a) Origin of sulfur in diet drives spatial and temporal mercury trends in seabird eggs from Pacific Canada 1968-2015. Environ Sci Technol 50: 13380-13386

* Elliott KH, Elliott JE (2016b) Lipid extraction techniques for stable isotope analysis of bird eggs: Chloroformmethanol leads to more enriched ${ }^{13} \mathrm{C}$ values than extraction via petroleum ether. J Exp Mar Biol Ecol 474:54-57

Elliott JE, Noble DG, Norstrom RJ, Whitehead PE (1989) Organochlorine contaminants in seabird eggs from the Pacific coast of Canada, 1971-1986. Environ Monit Assess 12:67-82

Elliott JE, Noble DG, Norstrom RJ, Whitehead PE, Simon M, Pearce PA, Peakall DB (1992) Patterns and trends of organic contaminants in Canadian seabirds, 1968-1990. In: Walker CH, Livingston DR (eds) Persistent pollutants in the marine environment. Pergamon Press, Oxford, p 181-194

* Ellis J, Wilhelm SI, Hedd A (2013) Mortality of migratory birds from marine commercial fisheries and offshore oil and gas production in Canada. Avian Conserv Ecol 8:4

Fairhurst GD, Bond AL, Hobson KA, Ronconi RA (2015) Feather-based measures of stable isotopes and corticosterone reveal a relationship between trophic position and physiology in a pelagic seabird over a 153-year period. Ibis 157:273-283

Farrell DJ (1998) Enrichment of hen eggs with n-3 longchain fatty acids and evaluation of enriched eggs in humans. Am J Clin Nutr 68:538-544

Folch J, Lees M, Sloane-Stanley GM (1957) A simple method for the isolation and purification of total lipides from animal tissues. J Biol Chem 226:497-509

Frith R, Krug D, Ronconi RA, Wong SNP, Mallory ML, McFarlane Tranquilla LA (2020) Diet of Leach's stormpetrels (Hydrobates leucorhous) among three colonies in Atlantic Canada. Northeast Nat (Steuben) 27:612-630
Gilbertson M, Elliott JE, Peakall DB (1987) Seabirds as indicators of marine pollution. In: Diamond AW, Fillion F (eds) The uses of birds. ICBP Technical Publication No. 6, Cambridge, p 231-248

* Gilmour ME, Lattin CR, Romero LM, Haussmann MF, Mauck RA, Dearborn DC (2015) Finding the best predictor of reproductive performance of Leach's storm-petrels. Auk 132:191-205

* Gjerdrum C, Ronconi RA, Turner KL, Hamer TE (2021) Bird strandings and bright lights at coastal and offshore industrial sites in Atlantic Canada. Avian Conserv Ecol $16: 22$

KGuglielmo CG (2018) Obese super athletes: fat-fueled migration in birds and bats. J Exp Biol 221:jeb165753

*Hansen J, Ruedy R, Sato M, Lo K (2010) Global surface temperature change. Rev Geophys 48:RG4004

* Hebert CE, Popp BN (2018) Temporal trends in a biomagnifying contaminant: application of amino acid compound specific stable nitrogen isotope analysis to the interpretation of bird mercury levels. Environ Toxicol Chem 37: 1458-1465

* Hebert CE, Wassenaar L (2001) Stable-nitrogen isotopes in waterfowl feathers reflect agricultural land use in western Canada. Environ Sci Technol 35:3482-3487

*Hebert CE, Weseloh DVC, Idrissi A, Arts MT and others (2008) Restoring piscivorous fish populations in the Laurentian Great Lakes causes seabird dietary change. Ecology 89:891-897

* Hebert CE, Weseloh DVC, Arts MT, de Solla SR, Moore DJ, Paterson G, Pekarik C (2020) Trends in herring gull egg quality over four decades reflect ecosystem state. J Gt Lakes Res 46:538-548

* Hedd A, Montevecchi WA, Davoren GK, Fifield DA (2009) Diets and distributions of Leach's storm-petrel (Oceanodroma leucorhoa) before and after an ecosystem shift in the Northwest Atlantic. Can J Zool 87:787-801

Hedd A, Pollet IL, Mauck RA, Burke CM and others (2018) Foraging areas, offshore habitat use, and colony overlap by incubating Leach's storm-petrels Oceanodroma leucorhoa in the Northwest Atlantic. PLOS ONE 13: e0194389

* Hixson SM, Arts MT (2016) Climate warming is predicted to reduce omega-3, long-chain, polyunsaturated fatty acid production in phytoplankton. Glob Change Biol 22: 2744-2755

*Hixson SM, Sharma B, Kainz MJ, Wacker A, Arts MT (2015) Production, distribution, and abundance of long-chain omega-3 polyunsaturated fatty acids: a fundamental dichotomy between freshwater and terrestrial ecosystems. Environ Rev 23:414-424

Hoyt DF (1979) Practical methods of estimating volume and fresh weight of bird eggs. Auk 96:73-77

*Hudson JM, Steinberg DK, Sutton TT, Graves JE, Latour RJ (2014) Myctophid feeding ecology and carbon transport along the northern Mid-Atlantic Ridge. Deep Sea Res I 93:104-116

Jónasdóttir SH (2019) Fatty acid profiles and production in marine phytoplankton. Mar Drugs 17:151

Krug DM, Frith R, Wong SNP, Ronconi RA, Wilhelm SI, O'Driscoll NJ, Mallory ML (2021) Marine pollution in fledged Leach's storm-petrels (Hydrobates leucorhous) from Baccalieu Island, Newfoundland and Labrador, Canada. Mar Pollut Bull 162:111842

* Lamarre J, Cheema SK, Robertson GJ, Wilson DR (2021) Omega-3 fatty acids accelerate fledging in an avian mar- 
ine predator: a potential role of cognition. J Exp Biol 224: jeb235929

Logan M (2007) Fatty acid analysis of the diet of Leach's storm-petrel. MSc thesis, Memorial University of Newfoundland, St. John's, NL

Mauck RA, Dearborn DC, Huntington CE (2018) Annual global mean temperature explains reproductive success in a marine vertebrate from 1955-2010. Glob Change Biol 24:1599-1613

McMeans BC, Koussoroplis A, Kainz MJ (2015) Effects of seasonal seston and temperature changes on lake zooplankton fatty acids. Limnol Oceanogr 60:573-583

Miller TW, Brodeur RD, Rau GH (2008) Carbon stable isotopes reveal relative contribution of shelf-slope production to the northern California Current pelagic community. Limnol Oceanogr 53:1493-1503

Miller A, Elliott JE, Elliott KH, Guigueno MF, Wilson LK, Lee S, Idrissi A (2014) Spatial and temporal trends in brominated flame retardants in seabirds from the Pacific coast of Canada. Environ Pollut 195:48-55

Minagawa M, Wada E (1984) Stepwise enrichment of ${ }^{15} \mathrm{~N}$ along food chains: further evidence and the relation between $\delta^{15} \mathrm{~N}$ and animal age. Geochim Cosmochim Acta 48:1135-1140

Pearce PA, Elliott JE, Peakall DB, Norstrom RJ (1989) Environmental contaminants in seabirds from the western north Atlantic, 1968-1984. Environ Pollut 56:217-235

Peterson BJ, Fry B (1987) Stable isotopes in ecosystem studies. Annu Rev Ecol Syst 18:293-320

Pollet IL, Shutler D (2018) Leach's storm petrel Oceanodroma leucorhoa population trends on Bon Portage Island, Canada. Seabird 31:73-80

Pollet IL, Bond AL, Hedd A, Huntington CE, Butler RG, Mauck R (2021) Leach's Storm-Petrel (Oceanodroma leucorhoa), version 1.1. In: Billerman SM, Keeney BK, Rodewald PG, Schulenberg TS (eds) Birds of the world. Cornell Lab of Ornithology, Ithaca, NY. https://birdsof theworld.org/bow/species/lcspet/cur/introduction

Post DM (2002) Using stable isotopes to estimate trophic position: models, methods, and assumptions. Ecology 83: 703-718

* Praetorius S, Rugenstein M, Persad G, Caldeira K (2018) Global and Arctic climate sensitivity enhanced by changes in North Pacific heat flux. Nat Commun 9:3124

Price ER, Sirsat SKG, Sirsat TS, Venables BJ, Dzialowski EM (2018) Rapid embryonic accretion of docosahexaenoic acid (DHA) in the brain of an altricial bird with an aquatic-based maternal diet. J Exp Biol 221:jeb183533

Rennie IRF, Green DJ, Krebs EA, Harfenist A (2020) High apparent survival of adult Leach's storm-petrels Oceanodroma leucorhoa in British Columbia. Mar Ornithol 48: 133-140

Robertson GJ, Russell J, Bryant R, Fifield DA, Stenhouse IJ (2006) Size and trends of Leach's storm-petrel Oceanodroma leucorhoa breeding populations in Newfoundland. Atl Seab 8:41-50

Rodríguez A, Arcos JM, Bretagnolle V, Dias MP and others (2019) Future directions in conservation research on petrels and shearwaters. Front Mar Sci 6:94

Rossoll D, Bermudez R, Hauss H, Schulz KG, Riebesell U, Sommer U, Winder M (2012) Ocean acidification-induced food quality deterioration constrains trophic transfer. PLOS ONE 7:e34737

Rudy MD, Kainz MJ, Graeve M, Colombo SM, Arts MT
(2016) Handling and storage procedures have variable effects on fatty acid content in fishes with different lipid quantities. PLoS ONE 11(8): e0160497

Sklepkovych BO, Montevecchi WA (1989) The world's largest known nesting colony of Leach's storm-petrels on Baccalieu Island, Newfoundland. Am Birds 43:38-42

* Stenhouse IJ, Montevecchi WA (1999) Indirect effects of the availability of forage fish and fisheries discards: gull predation on breeding storm-petrels. Mar Ecol Prog Ser 184: 303-327

Surai PF, Speake BK (2008) The natural fatty acid compositions of eggs of wild birds and the consequences of domestication. In: Meester F, Watson RR (eds) Wild-type food in health promotion and disease prevention: the Columbus concept. Humana Press, Totowa, NJ, p 121-137

* Surai PF, Bortolotti GR, Fidgett AL, Blount JD, Speake BK (2001) Effects of piscivory on the fatty acid profiles and antioxidants of avian yolk: studies on eggs of the gannet, skua, pelican and cormorant. J Zool (Lond) 255:305-312

Sweeting CJ, Polunin NV, Jennings S (2004) Tissue and fixative dependent shifts of $\delta^{13} \mathrm{C}$ and $\delta^{15} \mathrm{~N}$ in preserved ecological material. Rapid Commun Mass Spectrom 18: 2587-2592

Tostevin R, Turchyn AV, Farquhar J, Johnston DT, Eldridge DL, Bishop JKB, McIlvinet M (2014) Multiple sulfur isotope constraints on the modern sulfur cycle. Earth Planet Sci Lett 396:14-21

Twining CW, Brenna JT, Hairston NG Jr, Flecker A (2016a) Highly unsaturated fatty acids in nature: what we know and what we need to learn. Oikos 125:749-760

* Twining CW, Brenna JT, Lawrence P, Shipley JR, Tollefson TN, Winkler DW (2016b) Omega-3 long-chain polyunsaturated fatty acids support aerial insectivore performance more than food quantity. Proc Natl Acad Sci USA 113:10920-10925

* Twining CW, Shipley JR, Winkler DW (2018) Aquatic insects rich in omega-3 fatty acids drive breeding success in a widespread bird. Ecol Lett 21:1812-1820

*Vermeer K, Devito K (1988) The importance of Paracallisoma coecus and myctophid fishes to nesting fork-tailed and Leach's storm-petrels in the Queen Charlotte Islands, British Columbia. J Plankton Res 10:63-75

* Vermeer K, Devito K, Rankin L (1988) Comparison of nesting biology of fork-tailed (Oceanodroma furcata) and Leach's storm-petrels (O. leucorhoa). Colon Waterbirds 11:46-57

Wilhelm SI, Mailhiot J, Arany J, Chardine JW, Robertson GJ, Ryan PC (2015) Update and trends of three important seabird populations in the western North Atlantic using a geographic information system approach. Mar Ornithol 43:211-222

*Wilhelm SI, Hedd A, Robertson GJ, Mailhiot J, Regular PM, Ryan PC, Elliot RD (2020) The world's largest breeding colony of Leach's storm-petrel Hydrobates leucorhous has declined. Bird Conserv Int 30:40-57

*Wilhelm SI, Dooley SM, Corbett EP, Fitzsimmons MG, Ryan PC, Robertson GJ (2021) Effects of land-based light pollution on two species of burrow-nesting seabirds in Newfoundland and Labrador, Canada. Avian Conserv Ecol $16: 12$

Willacker JJ, Eagles-Smith CA, Ackerman JT (2017) Mercury bioaccumulation in estuarine fishes: novel insights from sulfur stable isotopes. Environ Sci Technol 51: 2131-2139 